
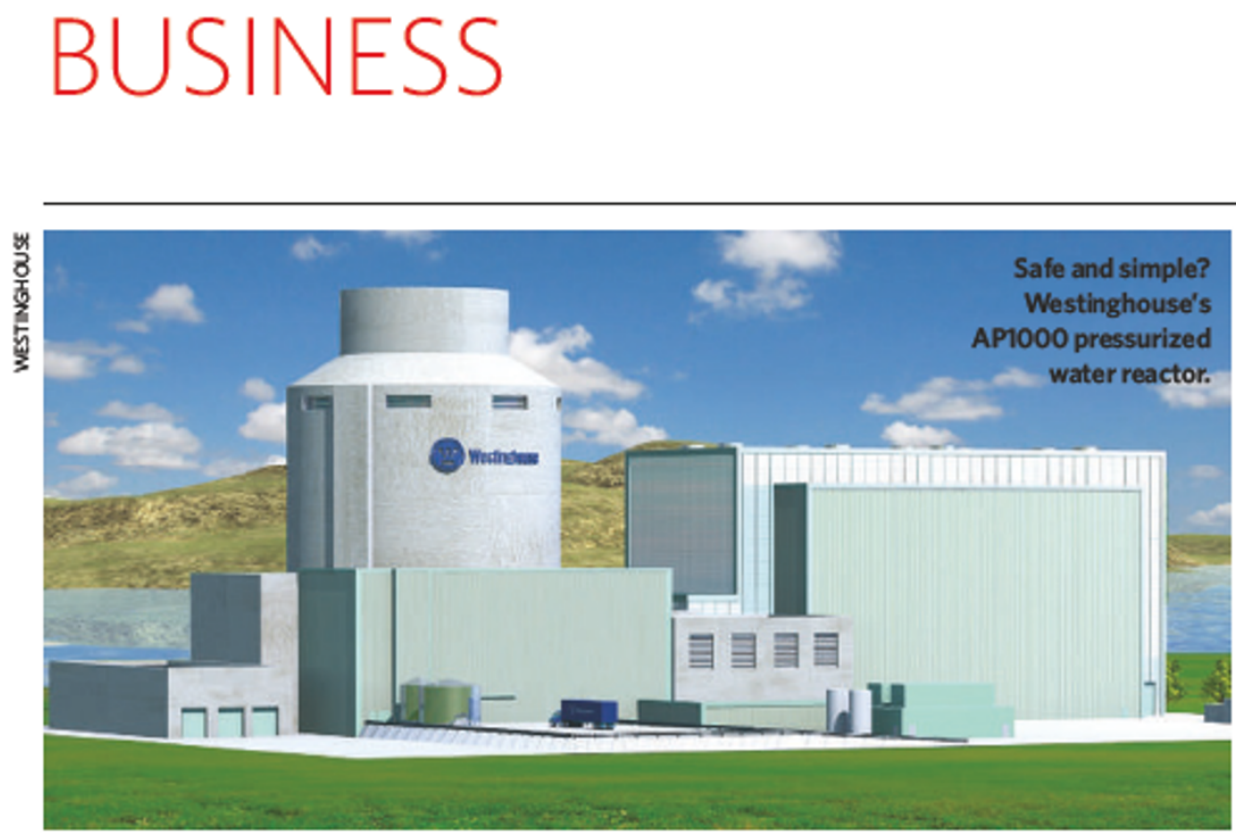

\title{
Toshiba goes nuclear
}

\section{A Japanese giant is betting big on nuclear power - but not everyone thinks the gamble will pay off, as Kurt Kleiner reports.}

W

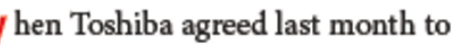

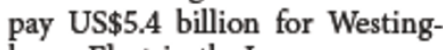
house Electric, the Japanese manufacturer placed a hefty bet that nuclear power is on the verge of a global comeback.

Toshiba paid British Nuclear Fuels (BNFL) more than five times as much as BNFL paid when it bought the Pittsburgh-based company in 1999. The high price surprised the markets, and Toshiba's shares dipped by about $3 \%$ on news of the acquisition. Some analysts questioned whether the Japanese electronics giant needs the hassle of controlling the world's largest supplier of nuclear power stations.

Westinghouse designed about half of the world's 400-odd commercially operating nuclear reactors. Last year, the company, which also sells nuclear fuel and operates and maintains nuclear plants, had sales of $\$ 1.8 \mathrm{bil}$ lion. In a statement, Toshiba said it expects to triple that by 2015. The company is particularly confident that it can win contracts from China, which is planning to place orders soon and complete 30 to 35 new nuclear plants by 2020 , at a total cost of about $\$ 50$ billion.

However, an even greater dividend would come from Toshiba's investment if other nations, such as India, Britain and the United States, decide to resume building nudear power stations.

According to the US Energy Information Administration $-\mathrm{a}$ branch of the federal government charged with predicting energy trends - global nuclear capacity will grow from 361 gigawatts now to 422 gigawatts in
2025. But that modest projected increase hides a large potential demand for new stations, as many existing ones are due for replacement.

Westinghouse builds pressurized water reactors. Favoured in China and the United States, these reactors use a contained loop of very hot water to heat a secondary cooling circuit, which produces steam to drive turbines. Toshiba already sells a different design, the boiling water reactor, in which steam from water boiled by nuclear fission drives turbines directly.

${ }^{\alpha}$ The Chinese market is the biggest game in town if you're a nuclear vendor," says Richard Lester, a nuclear engineer at the

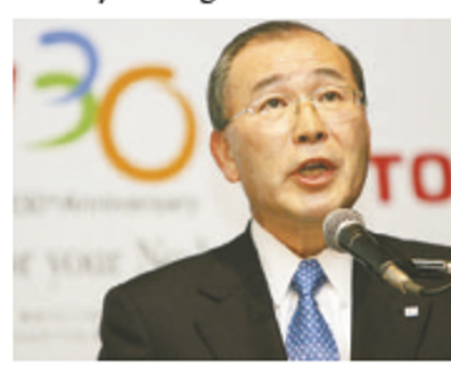

Toshiba boss Atsutoshi Nishida says its nuclear business will triple by 2015. utilities in the United States to abandon nuclear power for a quarter of a century.

The AP1000 instead uses a mixture of gravity, convection and condensation that will, its designers say, come naturally into play if the reactor malfunctions. Westinghouse claims that an AP1000 could safely last for three days after an accident without human intervention.

But it is unclear whether better safety features and fading memories of Three Mile Island will open the way to new nuclear plants in the United States. Despite the federal government's pledge to take responsibility for waste disposal, and to meet any liability greater than $\$ 10$ billion in the event of an accident, utilities have been slow to return to nuclear energy, deterred by controversy and the risks of delays in licensing and construction.

Still, nine US utilities have embarked on a licensing process that would allow them to build between 15 and 26 new nuclear plants in the next ten years. The applications aren't a commitment, and it is expected to be several years before any utility places an order. But they show revived investor interest in nuclear power, says Caren Byrd, an analyst with financial company Morgan Stanley in New York.

Backers say that nuclear power plants are needed to help meet global electricity demand, which is projected to almost double in the next 20 years, while reducing emissions of greenhouse gases.

Doubts about the viability of such plants Massachusetts Institute of Technology (MIT). "If you're a company like Toshiba, which until now has been focused on boiling-water reactor technology, acquiring Westinghouse puts you in the game in China.

Adding to the attraction for Toshiba is the Westinghouse AP1000, a new design that was certified in January by the US Nuclear Regulatory Commission. The AP1000 is a pressurized water reactor that uses 'passive' safety systems said to be simpler and more reliable than those of older reactors, which depended on pumps to cool an overheating reactor. It was such an overheating incident, at Three Mile Island in Pennsylvania in 1979, that led persist, however. A study in 。 2003 by researchers at MIT concluded that nuclear power was about $20 \%$ more expensive than gas and $50 \%$ dearer than coalfired plants. Higher fossilfuel prices have made nuclear power more competitive since then, says Lester, who co-authored the study, adding, however, that choosing nuclear ${ }^{\alpha}$ is by no means a clearcut decision for American power generators".

Daniel Kammen, a physicist at the University of California, Berkeley, who specializes in energy policy, says that the long-term economic prospects for nuclear power are still hazy, partly because the industry is so reliant on government subsidies.

But in the short term, China seems intent on going ahead with its reactors. And some new US reactors are likely to be built soon, says Kammen, who thinks the deal makes sense for Toshiba. 'It's an opportunity to acquire technology that's already certified in the United States," he says. "It's a very clever move." 